Article - Biological and Applied Sciences

\title{
Protective Effect of Rosa Canina Extract Against Doxorubicin-induced Testicular Toxicity in Mice
}

Fatemeh Nowrouzi ${ }^{1}$

https://orcid.org/0000-0002-7335-3187

Mehri Azadbakht ${ }^{1^{*}}$

https://orcid.org/0000-0003-3493-7785

\section{Eshrat Kalehoei ${ }^{1}$}

https://orcid.org/0000-0002-6504-9134

\section{Masoud Modarresi ${ }^{2}$}

https://orcid.org/0000-0001-6722-3434

${ }^{1}$ Razi University, Faculty of Basic Sciences, Department of Biology, Kermanshah, Iran; ${ }^{2}$ University of Medical Sciences, School of Pharmacy, Health Institute, Pharmaceutical Sciences Research Center, Kermanshah, Iran.

Received: 2018.01.15; Accepted: 2019.03.30.

*Correspondence: azadbakhtm_tmu@yahoo.com; Tel: :+988334274545; Fax:+988334274545.

\section{HIGHLIGHTS}

- Doxorubicin is able to target germ cells, and resulting in aspermia and infertility.

- $\quad$ R. canina extract treatment improve testicular and sperm parameters.

- R. canina extract has protective effects against doxorubicin-induced testicular toxicity.

Abstract: The present study was aimed to investigate the in vivo effects of Rosa canina extract on doxorubicin-induced testicular toxicity in mice for the first time. Male NMRI mice were randomly divided into six treatment groups (10=per group) as follows: (I) vehicles, (II) doxorubicin alone (3 mg/kg, i.p. on days 7, 14 and 21), (III and IV): Rosa canina extract alone (100 mg/kg and $200 \mathrm{mg} / \mathrm{kg}$ per day, i.p. for 28 days), (V and VI) Rosa canina extract plus doxorubicin (each dose given $1 \mathrm{~h}$ post Rosa canina). Doxorubicin-treated mice displayed smaller body and testicular weights, decreased serum levels of testosterone, loss in the number of germ cells and Sertoli cells, and reduced sperm count, viability, morphology 
Nowrouzi, F.; et al.

and motility. Doxorubicin treatment significantly decreased the mean testis diameter, seminiferous tubular diameter and seminiferous epithelial height and increased seminiferous luminal diameter. However, Rosa canina pretreatment could effectively improve all of these abnormalities in doxorubicin- treated mice. The treatment with a higher dose of the extract (200 mg/kg) was more effective compared to doxorubicin and the lower dose of the extract. These findings suggested that the Rosa canina extract has protective effects against doxorubicin-induced reproductive toxicity.

Keywords: Rosa canina extract, Doxorubicin, Testes, Sperm, Mice.

\section{INTRODUCTION}

Doxorubicin, one of the most well-known chemotherapeutic agents, has long been widely used for its potent efficiency to treat both solid and non-solid malignant tumors $[1,2]$. However, its clinical use has been accompanied by adverse effects on the male reproductive system [3]. The exact mechanism of doxorubicin-induced testicular toxicity is little known, but previous studies have provided evidences that doxorubicin retards testicular growth, impedes the process of spermatogenesis, which eventually leads to male infertility through imposing oxidative stress and cellular apoptosis [4]. The drug intercalates into DNA strands and results in double-strand DNA breaks and cell death $[1,2,5]$ in meiotically dividing spermatocytes and spermatogonia [6-10]. Moreover, doxorubicin-induced oxidative stress [2] in testicular tissue may also cause DNA damage and cell death [4].

The high susceptibility of testes and sperm to doxorubicin -induced testicular oxidative stress may be due to a weak anti-oxidant defense system in testicular tissue and semen [4,11-13]. Besides, earlier studies demonstrated that antioxidant supplementation improved the quality of the semen profile in infertile men [14]. Based on this concept, a variety of antioxidants have been employed to protect the testes from doxorubicin injury $[15,16,4]$.

Rosa canina ( $R$. canina), a member of the Rosaceae family [17] have been studied as antioxidant and anti-inflammatory agents [18]. High antioxidant power of $R$. canina is mainly due to its strong free radical scavenging and hydrogen peroxide scavenging activities [19]. Such activities can be attributed to the presence of the active constituents [20] such as phenolic acids, proanthocyanidins, flavonoids, unsaturated and polyunsaturated fatty acids, phospholipids, minerals, carotenoids and highest vitamin $\mathrm{C}$ content (ascorbic acid) and other vitamins (vitamins B1(thiamin), B2, K, PP [21,17]. In addition, $R$. canina has been considered as a protective agent against DNA damage [22]. However, despite its clinical effectiveness as diuretic, arthritis, laxative, kidney function disturbances, urinary tract disorders, colds, gout, fever, and gastroprotective agents [21,23]; the impact of this extract on spermatogenesis and male infertility has not been reported yet. Considering the widespread use clinically of doxorubicin against malignant tumors and its consequences to male fertility [2,3], and the protective effect of $R$. canina extract over some other tissues, we decided to study the in vivo protective effects of $R$. canina against doxorubicin-induced testicular toxicity in mice. 


\section{MATERIAL AND METHODS}

\section{Plant material and preparation of the aqueous extract}

The fruits of Rosa canina were collected from Parav Mountain in Kermanshah province (west of Iran). A dried voucher specimen (No, 578) was deposited in the Herbarium of Biology Department, Razi University (HBRU). Fruits were washed and dried with a clean cloth. Pulps of the fruits were separated and divided into small pieces. The crushed pulps were dried in an oven at $60^{\circ} \mathrm{C}$ for 24 hours. Dried pulps were milled and stored in a closed container at $-20{ }^{\circ} \mathrm{C}$ until extraction. Fifty grams of dried powder of $\mathrm{R}$. canina pulp was extracted on the stirrer with $1000 \mathrm{ml}$ of distilled water for $24 \mathrm{~h}$ at room temperature. After filtration, the aqueous extract was evaporated to dryness on a rotary evaporator under reduced pressure below $40^{\circ} \mathrm{C}$.

\section{Animals and pharmacological treatments}

Male NMRI mice were obtained from the Experimental Animal Facility of the Pasteur Institute (Tehran, Iran), housed under standard conditions of controlled humidity, temperature $\left(25 \pm 2^{\circ} \mathrm{C}\right)$ and light $(12 \mathrm{~h}$ light/12 h dark), and fed with commercial pellet and water during the study period. Animal handling and care were performed in accordance with the policies of the Razi University Animal Care and Use Committee, and the Guide for the Care and Use of Laboratory Animals (B/195). Male NMRI mice were divided randomly into six treatment groups (10 mice per group) and caged separately as follows: treatment I: mice served as control group and received none but a normal saline injection; treatment II: mice were treated with doxorubicin (Milan, Italy) at the dose of $3 \mathrm{mg} / \mathrm{kg}$ on day 7,14 and 21 for totally three shots and accumulated dose of $9 \mathrm{mg} / \mathrm{kg}$; treatment III and IV: mice were given R. canina extract 100 and $200 \mathrm{mg} / \mathrm{kg}$ for 28 days, respectively; treatment $\mathrm{V}$ and $\mathrm{VI}$ : mice were received $\mathrm{R}$. canina extract 100 and $200 \mathrm{mg} / \mathrm{kg}$ followed by doxorubicin injection ( 3 $\mathrm{mg} / \mathrm{kg}$, each dose given $1 \mathrm{~h}$ after $\mathrm{R}$. canina), respectively. All the treatments were given by intraperitoneal route.

\section{Harvest of serum and testicular samples}

Experimental and control animals were killed by cervical dislocation, on day 28 after the first treatment, and the body and testicular weights were measured in all treatment groups. For to do histopathologic and morphometric examinations, their testis fixed in $10 \%$ buffered formalin for 24 hours, dehydrated by gradually increasing concentrations of ethanol and embedded in paraffin. Five micrometer cross sections were stained with hematoxylin and eosin (H\&E). The epididymal cauda were obtained for the analysis of sperm concentration, viability, motility and morphology. Blood samples were harvested and centrifuged at $2000 \times \mathrm{g}$ for $10 \mathrm{~min}$ to obtain serum for evaluating serum testosterone concentrations.

\section{Epididymal sperm count and viability}

The epididymal cauda of each mouse were excised and cut into small pieces in a petri dishes containing Ham's F-10 culture medium (nutrient mixture-Ham-X1, Gibco, UK) supplemented with $10 \%$ fetal bovine serum (FBS; Gibco). The samples incubated for 30 minutes at $37^{\circ} \mathrm{C}$ to let the sperms swim up [24]. To assess the epididymal sperm count and 
viability, $10 \mu \mathrm{l}$ of $0.4 \%$ trypan blue dye ( $\mathrm{v} / \mathrm{v}$; Gibco) was added to $40 \mu \mathrm{l}$ of the sperm sample and incubated at room temperature for $5 \mathrm{~min}$. Then, the specimen was transferred to Neubauer's counting chamber of hemacytometer. The total number of viable (colorless) and dead (colored) sperms were counted with using a light microscope at $40 \times$ magnifications. The relative viability of sperms was calculated by dividing the total viable sperms (unstained) by the total sperms (stained and unstained) $\times 100$ [25].

\section{Sperm motility}

One drop of the sperm homogenate was placed on a pre-warmed microscope slide at $37^{\circ} \mathrm{C}$, and cover with a clean cover slip. Photographs were taken in 30 frames per second in each sample and recorded by a digital camera (Olympus DP72 Digital Camera; Tokyo, Japan) attached to inverted fluorescence microscope (Olympus IX-71, Japan). At least 400 sperm were counted for sperm motility analysis per sample with $\times 400$ magnification. Sperm progression was classified as follows: rapid progressive, slow progressive, non-progressive and immotile [26,27].

\section{Sperm morphology}

For sperm morphology assessment, a drop of sperm suspension was drawn on clean glass slide. The sperms were fixed in ethanol alcohol and allowed to dry in air overnight. The slides were stained with papanicolaou staining technique and examined at $\times 400$ magnification to detect the morphological abnormalities as follows: pin head, round head, giant head, double head, bent neck, coiled tail, bent tail, short tail, double tail and cytoplasmic droplet. For each sperm sample, the percentage of abnormal sperms was scored from at least 10 fields and 200 sperms [26,27].

\section{Serum testosterone concentration}

Serum testosterone concentrations were determined by using AccBind ELISA Microwells (testosterone ELISA kit) (Monobind Inc., USA) [28].

\section{Histopathological analysis}

To assess histopathological alterations, two hundred round or nearly round seminiferous tubule cross-sections per animal were examined. The cross-sections of tubular profiles were categorized into four grades, $1=0-25 \% ; 2=26-50 \% ; 3=51-75 \% ; 4=$ $76-100 \%$. These alterations were categorized according to the level of damage observed in the seminiferous epithelium of tubular profiles and the frequency of occurrence in each treatment group. The determinant histopathological alterations were considered: a) the germinal lineage cells detached from the epithelium into the tubular lumen, b) intraepithelial vacuolation formation, $c$ ) the cellular debris $d$ ) the depletion of epithelial (depletion level 1: Sertoli cell-only; depletion level 2: Sertoli cell + spermatogonia; depletion level 3: At least two layers of cells). The images were captured using an inverted fluorescence microscope (Olympus IX-71, Japan) [29]. 


\section{Morphometrical analysis}

Testis sections used for morphometrical analysis were examined and photographed by an inverted fluorescence microscope (Olympus IX-71, Japan). Testicular diameter; seminiferous tubule diameter; luminal diameter and germinal epithelium height $(\mu \mathrm{m})$ were measured in each treatment group. From the spermatogenic cells on the inner surface of the basement membrane lining the lumen of the tubules considered for measurement of diameter and germinal epithelial height [30]. For this, two hundred round or nearly round cross-sections of tubular profiles per animal were examined at $\times 100$ magnification.

\section{Tubular frequency according to the different germ cell types}

To determine alterations in the kinetics of spermatogenesis, the frequencies of tubular sections containing each germ cell type (spermatogonia, spermatocytes, round spermatids and elongated spermatids) and Sertoli cells at the stage VII of the spermatogenic cycle were assessed. For this, two hundred random tubular sections from 20 random testicular cross-sections per animal were examined at $\times 100$ magnifications. The identification of germ cell types and stage VII of the seminiferous epithelium cycle was performed according to Nakata and co-workers [30,31].

\section{Statistical analysis}

All data were analyzed by using SPSS (version 20; SPSS Inc) and were expressed as mean and standard errors of the means (SEM). The statistical significance was tested by one-Way ANOVA and Duncan test. A value of $p<0.05$ was considered to determine statistically significant.

\section{RESULTS}

\section{The body and testicular weights}

The body weight, absolute and relative weight of testis in treatment II showed a significantly decrease in comparison to all the other treatment groups $(p<0.05)$ (fig. $1 \mathrm{~A}, \mathrm{~B}$ and $\mathrm{C}$ ). However, these parameters were not significantly affected by any of treatment III and IV when compared with treatment I. In addition, no significant differences were observed regarding the body weight in the treatment $\mathrm{V}$ and $\mathrm{VI}$ compared with treatment $\mathrm{I}$. Absolute and relative weight of testis in the treatment $\mathrm{V}$ and $\mathrm{VI}$ significantly restored than treatment II, respectively $(p<0.05)$. 


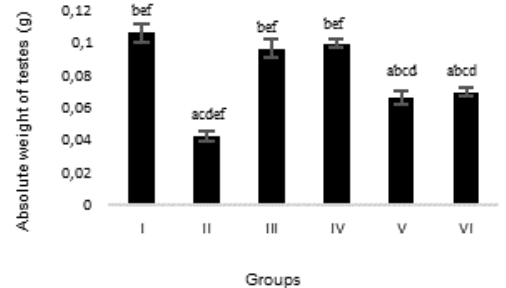

(b)

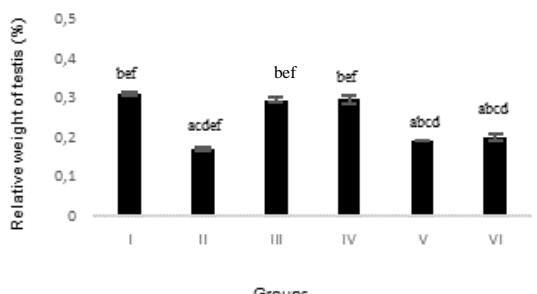

(c)

Figure 1. Body weight (A), absolute weight of testis (B) relative weight (per BW, \%) (C) in mice treated with doxorubicin and $R$. canina. Treatment I: control; Treatment II: doxorubicin; Treatment III: $R$. canina extract $100 \mathrm{mg} / \mathrm{kg}$; Treatment IV: $R$. canina extract $200 \mathrm{mg} / \mathrm{kg}$; Treatment V: $R$. canina100 $\mathrm{mg} / \mathrm{kg}$ /doxorubicin; Treatment VI: $R$. canina $200 \mathrm{mg} / \mathrm{kg} /$ doxorubicin (mean + SEM; $\mathrm{P}<0.05$ ). a

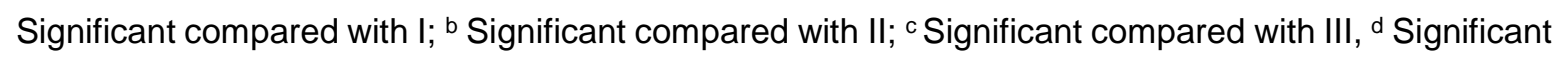

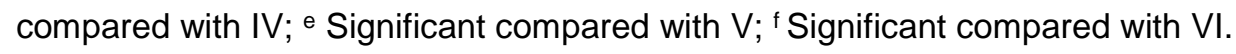

\section{Sperm count and viability}

The results of the sperm count and the percentages of sperm viability were significantly lower in the treatment II in comparison to all the other treatment groups $(p<0.05)$ (Tab. 1). In contrast, there was a significant increase in these parameters in the treatment III and IV compared with all the other treatment groups, respectively $(\mathrm{p}<0.05)$. In addition, the mean sperm count and the percentages of sperm viability in the treatment $\mathrm{V}$ and $\mathrm{VI}$ were significantly higher than treatment $I$, respectively $(p<0.05)$. Changes in these parameters were dose-dependent manner in response to R. canina extract (treatment III and IV, and V and $\mathrm{VI}$, respectively).

Table 1. Frequency of mouse sperm count and viability after treatment with doxorubicin and $R$. canina extract.

\begin{tabular}{lcc}
\hline Groups & Sperm count $\left(\times 10^{6}\right)$ & Sperm viability (\%) \\
\hline Treatment I & $16.40 \pm 0.22^{\mathrm{b}, \mathrm{c}, \mathrm{d}, \mathrm{e}, \mathrm{f}}$ & $77.32 \pm 0.76^{\mathrm{b}, \mathrm{c}, \mathrm{d}, \mathrm{e}, \mathrm{f}}$ \\
Treatment II & $8.52 \pm 0.23^{\mathrm{a}, \mathrm{c}, \mathrm{d}, \mathrm{e}, \mathrm{f}}$ & $47.36 \pm 1.22^{\mathrm{b}, \mathrm{c}, \mathrm{d}, \mathrm{e}, \mathrm{f}}$ \\
Treatment III & $17.80 \pm 0.20^{\mathrm{a}, \mathrm{b}, \mathrm{d}, \mathrm{e}, \mathrm{f}}$ & $81.47 \pm 0.90^{\mathrm{a}, \mathrm{b}, \mathrm{e}, \mathrm{f}}$ \\
Treatment IV & $19.08 \pm 0.24^{\mathrm{a}, \mathrm{b}, \mathrm{c}, \mathrm{e}, \mathrm{f}}$ & $82.41 \pm 1.05^{\mathrm{a}, \mathrm{b}, \mathrm{e}, \mathrm{f}}$ \\
Treatment V & $11.88 \pm 0.27^{\mathrm{a}, \mathrm{b}, \mathrm{c}, \mathrm{d}, \mathrm{f}}$ & $70.38 \pm 1.26^{\mathrm{a}, \mathrm{b}, \mathrm{c}, \mathrm{d}}$ \\
Treatment VI & $14.52 \pm 025^{\mathrm{a}, \mathrm{b}, \mathrm{c}, \mathrm{d}, \mathrm{e}}$ & $73.07 \pm 1.75^{\mathrm{a}, \mathrm{b}, \mathrm{c}, \mathrm{d}}$ \\
\hline
\end{tabular}

Treatment I: control; Treatment II: doxorubicin; Treatment III: $R$. canina extract $100 \mathrm{mg} / \mathrm{kg}$; Treatment IV: $R$. canina extract $200 \mathrm{mg} / \mathrm{kg}$; Treatment V: $R$. canina100 mg/kg /doxorubicin; Treatment VI: $R$. canina $200 \mathrm{mg} / \mathrm{kg} /$ doxorubicin (mean + SEM; P < 0.05). a Significant compared with I; b Significant compared with II; c Significant compared with III, d Significant compared with IV; e Significant compared with $\mathrm{V}$; ${ }^{\dagger}$ Significant compared with $\mathrm{VI}$.

\section{Sperm motility}

Based on the results, there was a significant decrease in the mean percentage of sperm progressivity and non-progressivity and a significant increase in the mean percentage of immotile sperm in the treatment II compared with all the other the treatment groups, 
respectively $(p<0.05)$ (Tab. 2$)$. Reversibly, the percentage of progressive motility was significantly higher in the treatment III and IV than treatment I as well as in the treatment V and $\mathrm{VI}$ than the treatment $\mathrm{II}$, respectively $(\mathrm{p}<0.05)$. The mean percentage of slow progressive sperm was noted when the treatment $\mathrm{V}$ and $\mathrm{VI}$ compared with all the treatment groups $(p<0.05)$. The mean percentage of immotile sperm was significantly lower in the treatment III and IV than treatment I as well as the treatment V and VI than treatment II, respectively $(p<0.05)$. However, no significant differences were observed regarding the mean percentage of immotile sperm in the treatment $\mathrm{V}$ and $\mathrm{VI}$ compared with treatment I. In addition, sperm non-progressivity in the treatment IV was significantly lower than treatment I $(\mathrm{p}<0.05)$.

Table 2. Frequency of mouse sperm motility after treatment with doxorubicin and $R$. canina extract.

\begin{tabular}{ccccc}
\hline Groups & Fast progressive (\%) & $\begin{array}{c}\text { Slow progressive } \\
(\%)\end{array}$ & $\begin{array}{c}\text { Non-progressive } \\
(\%)\end{array}$ & Immotile (\%) \\
\hline Treatment I & $40.80 \pm 1.65^{\mathrm{b}, \mathrm{c}, \mathrm{d}}$ & $16.60 \pm 0.93^{\mathrm{e}, \mathrm{f}}$ & $18.60 \pm 1.20^{\mathrm{b}, \mathrm{d}}$ & $24.00 \pm 0.89^{\mathrm{b}, \mathrm{c}, \mathrm{d}}$ \\
Treatment II & $6.00 \pm 1.04^{\mathrm{a}, \mathrm{c}, \mathrm{d}, \mathrm{e}, \mathrm{f}}$ & $15.40 \pm 1.02^{\mathrm{e}, \mathrm{f}}$ & $6.60 \pm 0.87^{\mathrm{a}, \mathrm{c}, \mathrm{d}, \mathrm{e}, \mathrm{f}}$ & $72.20 \pm 2.03^{\mathrm{a}, \mathrm{c}, \mathrm{d}, \mathrm{e}, \mathrm{f}}$ \\
Treatment III & $51.20 \pm 1.39^{\mathrm{a}, \mathrm{b}, \mathrm{e}, \mathrm{f}}$ & $16.20 \pm 0.86^{\mathrm{e}, \mathrm{f}}$ & $15.60 \pm 0.92^{\mathrm{b}}$ & $18.00 \pm 1.26^{\mathrm{a}, \mathrm{b}, \mathrm{e}, \mathrm{f}}$ \\
Treatment IV & $52.80 \pm 2.70^{\mathrm{a}, \mathrm{b}, \mathrm{e}, \mathrm{f}}$ & $15.60 \pm 1.02^{\mathrm{e}, \mathrm{f}}$ & $14.20 \pm 0.86^{\mathrm{a}, \mathrm{b}}$ & $17.00 \pm 0.70^{\mathrm{a}, \mathrm{b}, \mathrm{e}, \mathrm{f}}$ \\
Treatment V & $38.80 \pm 1.24^{\mathrm{b}, \mathrm{c}, \mathrm{d}}$ & $20.40 \pm 1.43^{\mathrm{a}, \mathrm{b}, \mathrm{c}, \mathrm{d}}$ & $17.20 \pm 1.28^{\mathrm{b}}$ & $22.80 \pm 0.86^{\mathrm{b}, \mathrm{c}, \mathrm{d}}$ \\
Treatment VI & $40.40 \pm 1.50^{\mathrm{b}, \mathrm{c}, \mathrm{d}}$ & $21.00 \pm 1.22^{\mathrm{a}, \mathrm{b}, \mathrm{c}, \mathrm{d}}$ & $16.20 \pm 1.01^{\mathrm{b}}$ & $22.40 \pm 0.93^{\mathrm{b}, \mathrm{c}, \mathrm{d}}$ \\
\hline
\end{tabular}

Treatment I: control; Treatment II: doxorubicin; Treatment III: R. canina extract $100 \mathrm{mg} / \mathrm{kg}$; Treatment IV: $R$. canina extract $200 \mathrm{mg} / \mathrm{kg}$; Treatment V: $R$. canina100 mg/kg /doxorubicin; Treatment VI: $R$. canina $200 \mathrm{mg} / \mathrm{kg} /$ doxorubicin (mean + SEM; P < 0.05). a Significant compared with I; b Significant compared with II; ' Significant compared with III, d Significant compared with IV; e Significant

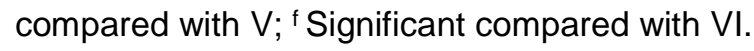

\section{Sperm morphology}

Level of sperm abnormality was significantly higher in the treatment II when compared with all the other groups $(p<0.05)(T a b .3$; fig. 2). However, no significant differences were observed in the treatment III and IV compared with treatment I. In addition, level of sperm abnormality in the treatment $\mathrm{V}$ and $\mathrm{VI}$ were significantly lower than treatment II, respectively $(p<0.05)$. 

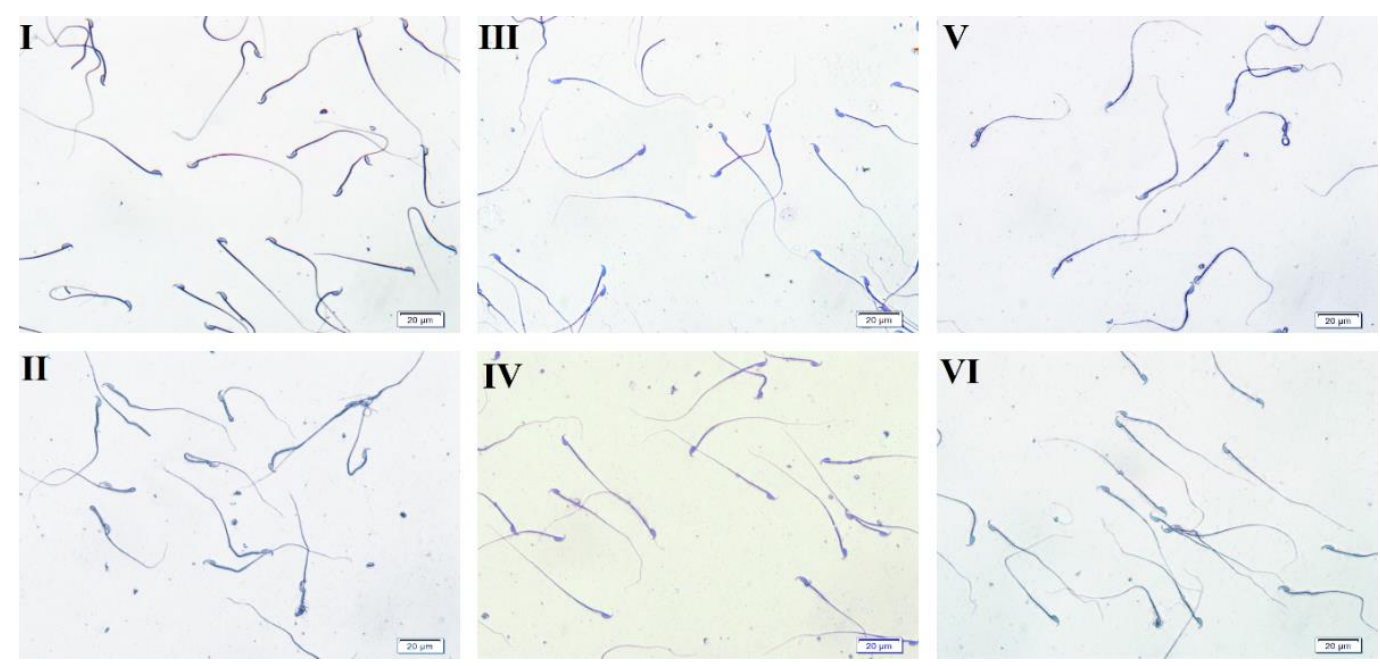

Figure 2. Effect of doxorubicin and Rosa canina on sperm morphology, Pap staining, Magnification of 40X. Treatment I: control; Treatment II: doxorubicin; Treatment III: $R$. canina extract $100 \mathrm{mg} / \mathrm{kg}$; Treatment IV: $R$. canina extract $200 \mathrm{mg} / \mathrm{kg}$; Treatment V: $R$. canina100 $\mathrm{mg} / \mathrm{kg} /$ doxorubicin; Treatment VI: $R$. canina $200 \mathrm{mg} / \mathrm{kg} /$ doxorubicin.

Table 3. Frequency of abnormal morphology of mouse sperm after treatment with doxorubicin and $R$. canina extract.

\begin{tabular}{ccccccc}
\hline Groups & Treatment I & Treatment II & Treatment III & Treatment IV & Treatment V & Treatment VI \\
\hline abnormal (\%) & $29.60 \pm 1.96^{\text {bef }}$ & $74.40 \pm 1.63^{\text {acdef }}$ & $27.80 \pm 1.28^{\text {bef }}$ & $27.00 \pm 1.70^{\text {bef }}$ & $60.60 \pm 1.95^{\mathrm{abcd}}$ & $55.80 \pm 1.43^{\mathrm{abcd}}$ \\
\hline
\end{tabular}

Treatment I: control; Treatment II: doxorubicin; Treatment III: $R$. canina extract $100 \mathrm{mg} / \mathrm{kg}$; Treatment IV: $R$. canina extract $200 \mathrm{mg} / \mathrm{kg}$; Treatment V: $R$. canina100 mg/kg /doxorubicin; Treatment VI: $R$. canina $200 \mathrm{mg} / \mathrm{kg} /$ doxorubicin (mean + SEM; P < 0.05). a Significant compared with I; ' Significant compared with II; c Significant compared with III, d Significant compared with IV; e Significant compared with V; f Significant compared with VI.

\section{Serum testosterone level}

Serum testosterone levels were significantly lower in the treatment II compared to other treatment groups $(p<0.05)$. In contrast, the levels were higher in the treatment III and IV compared to treatment I, but the effect was significant only in IV than treatment I $(p<0.05)$. Serum testosterone levels in the treatment $\mathrm{V}$ and $\mathrm{VI}$ were also significantly higher than treatment II, respectively ( $p<0.05)$ (fig. 3). 


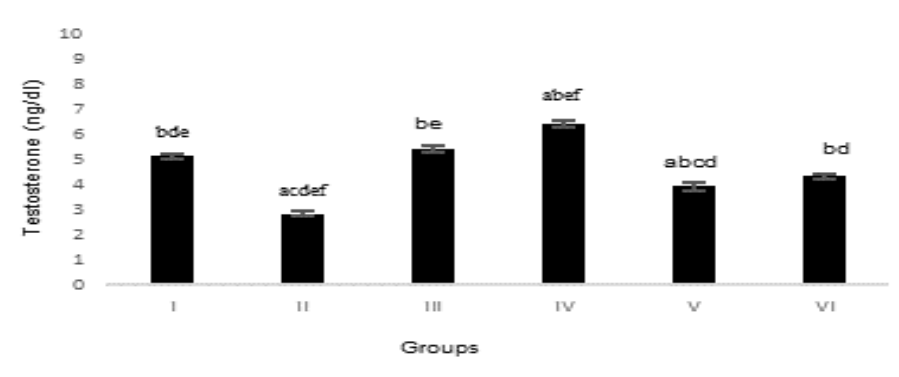

Figure 3. Comparison of the means of serum testosterone concentration after treatment with doxorubicin and $R$. canina extract. Treatment I: control; Treatment II: doxorubicin; Treatment III: $R$. canina extract $100 \mathrm{mg} / \mathrm{kg}$; Treatment IV: $R$. canina extract $200 \mathrm{mg} / \mathrm{kg}$; Treatment V: $R$. canina100 $\mathrm{mg} / \mathrm{kg} /$ doxorubicin; Treatment VI: $R$. canina $200 \mathrm{mg} / \mathrm{kg} /$ doxorubicin (mean + SEM; $\mathrm{P}<0.05)$. a Significant compared with I; b Significant compared with II; c Significant compared with III, d Significant

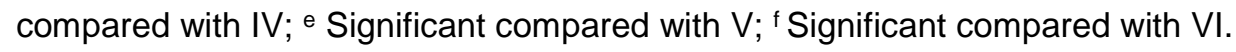

\section{Histopathology}

The affected seminiferous tubules of treatment II exhibited a high frequency of tubules with germ cell depletion and degenerated appearance of germ cells, sometimes the seminiferous epithelium lined only with Sertoli cells (depletion level 1) (Tab. 4; fig. 4) $(p<0.05)$. In addition, the germinal lineage cells detached from the epithelium into the tubular lumen, intraepithelial vacuolization and cellular debris was noticed in the tubular lumen of many seminiferous tubules in the treatment II $(p<0.05)$. Conversely, there was a normal preserved seminiferous epithelium in the treatment III and IV, similar to those observed in treatment I, respectively. In addition, tubular sections in the treatment $\mathrm{V}$ and $\mathrm{VI}$ displayed a lower frequency of tubular sections with germ cell depletion (severe and moderate) than treatment II, respectively $(p<0.05)$. The lower presence of intraepithelial vacuoles and sloughed germ cell into the lumen were observed in these treatment groups, respectively $(p<0.05)$.
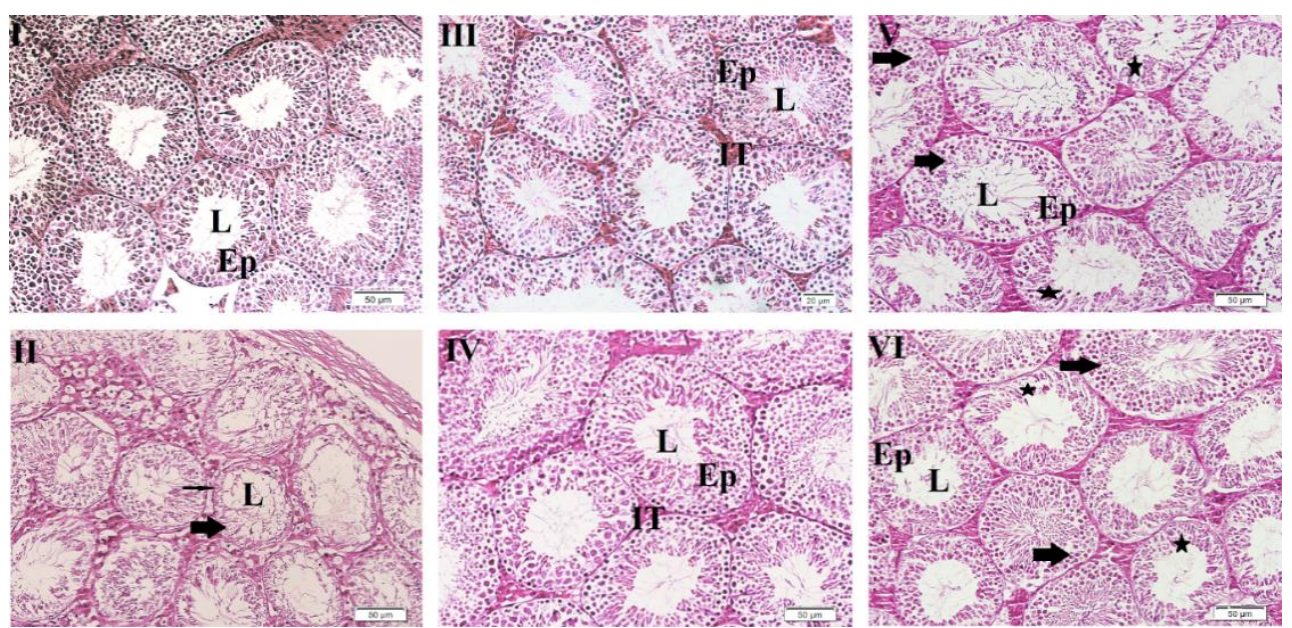

Figure 4. Photomicrographs of cross sections of seminiferous tubules of Treatment I: control; Treatment II: doxorubicin; Treatment III: $R$. canina extract $100 \mathrm{mg} / \mathrm{kg}$; Treatment IV: $R$. canina extract $200 \mathrm{mg} / \mathrm{kg}$; Treatment V: $R$. canina100 mg/kg /doxorubicin; Treatment VI: $R$. canina $200 \mathrm{mg} / \mathrm{kg}$ /doxorubicin. H\&E method. I, III, IV; showing organized seminiferous epithelium (Ep) with normally 
different germ cell layers containing various cell types, tubular lumen (L); interstitial tissue (IT). Observe some tubular sections in II showing the cellular debris, intraepithelial vacuolation formation (thick arrow), the germinal lineage cells detached from the epithelium into the tubular lumen and depletion of epithelial such as Sertoli cell-only (thin arrows). V and VI; in both figures, note damaged seminiferous epithelium in seminiferous tubule (asterisks) neighboring other seminiferous epithelium containing normally different germ cell layers (thick arrow).

Table 4. Percentage of mice presenting specific histopathological alterations and score of the frequencies $(1-4)^{1}$ of the tubular alterations after treatment with doxorubicin and $R$. canina extract.

Types of histological alterations

\begin{tabular}{|c|c|c|c|c|c|c|c|}
\hline & & I & II & III & IV & V & VI \\
\hline Sloughed germinal cell into & Percentage of mice with this alteration & 10 be & 100 acdef & 10 be & 10 be & 20 abcdf & 10 be \\
\hline the lumen. & Score of frequency of the tubular alteration & 1 & 4 & 1 & 1 & 1 & 1 \\
\hline Intraepithelial & Percentage of mice with this alteration & 10 be & 100 acdef & 10 be & 10 be & 20 abcdf & 10 be \\
\hline vacuolization. & Score of frequency of the tubular alteration & 1 & 4 & 1 & 1 & 1 & 1 \\
\hline Sertoli cell-only & Percentage of mice with this alteration & 0 bef & 100 acdef & 0 bef & 0 bef & 20 abf & 10 abcde \\
\hline (depletion level 1). & Score of frequency of the tubular alteration & 1 & 4 & 1 & 1 & 2 & 1 \\
\hline Sertoli cell + spermatogonia & Percentage of mice with this alteration & 0 bef & 100 acdef & $0^{\text {bef }}$ & 0 bef & 60 abcdf & 30 abcde \\
\hline (depletion level 2). & Score of frequency of the tubular alteration & 1 & 4 & 1 & 1 & 2 & 1 \\
\hline At least two layers of cells & Percentage of mice with this alteration & 0 bcef & 100 acdef & 10 abdef & 0 bcef & 40 abcdf & 30 abcde \\
\hline (depletion level 3). & Score of frequency of the tubular alteration & 1 & 4 & 1 & 1 & 2 & 2 \\
\hline
\end{tabular}

${ }^{1}$ Scores 1-4: $1=0-25 \% ; 2=26-50 \% ; 3=51-75 \% ; 4=76-100 \%$. Treatment I: control; Treatment II: doxorubicin; Treatment III: R. canina extract $100 \mathrm{mg} / \mathrm{kg}$; Treatment IV: $R$. canina extract $200 \mathrm{mg} / \mathrm{kg}$; Treatment V: $R$. canina $100 \mathrm{mg} / \mathrm{kg} /$ doxorubicin; Treatment VI: $R$. canina $200 \mathrm{mg} / \mathrm{kg} /$ doxorubicin

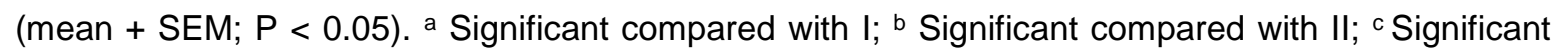
compared with III, d Significant compared with IV; e Significant compared with V; ${ }^{\dagger}$ Significant compared with VI.

\section{Morphometric testicular analysis}

Based on the results, there was a significant decrease in the mean testicular diameter, seminiferous tubular diameter and height of the seminiferous tubule epithelium in the treatment II $(p<0.05)$. Conversely, luminal diameter in this treatment had a significant increase compared to the values observed in treatment I $(p<0.05)$. An increase in the mean seminiferous tubular diameter and seminiferous epithelial height was seen in the treatment III and IV than treatment I, respectively. The increase was significant only in treatment IV $(p<0.05)$. These values significantly restored in the treatment $\mathrm{V}$ and $\mathrm{VI}$ compared to treatment II, respectively $(p<0.05)$. Despite decrease in the mean seminiferous luminal diameter in two treatment groups compared to treatment II, the difference was significant only in treatment $\mathrm{VI}(\mathrm{p}<0.05)$ (Tab. 5; fig. 4). 
Table 5. Values of testicular histomorphometrical parameters after treatment with doxorubicin and $R$. canina extract.

\begin{tabular}{ccccc}
\hline Groups & $\begin{array}{c}\text { Testicular } \\
\text { diameter } \\
(\mu \mathrm{m})\end{array}$ & $\begin{array}{c}\text { Seminiferous } \\
\text { tubular diameter } \\
(\boldsymbol{\mu m})\end{array}$ & $\begin{array}{c}\text { Seminiferous } \\
\text { epithelial height } \\
(\boldsymbol{\mu m})\end{array}$ & $\begin{array}{c}\text { Seminiferous } \\
\text { luminal diameter } \\
(\boldsymbol{\mu m})\end{array}$ \\
\hline Treatment I & $3410.36 \pm 21.2^{\text {bef }}$ & $229.23 \pm 3.12^{\text {bdef }}$ & $73.22 \pm 1.77^{\text {bdef }}$ & $80.75 \pm 2.91^{\text {be }}$ \\
Treatment II & $2795.25 \pm 53.2^{\text {acdef }}$ & $176.92 \pm 2.22^{\text {acdef }}$ & $35.99 \pm 1.70^{\text {acdef }}$ & $101.40 \pm 2.66^{\text {acdf }}$ \\
Treatment III & $3342.14 \pm 63.3^{\text {bdef }}$ & $234.46 \pm 2.70^{\text {bdef }}$ & $76.73 \pm 1.99^{\text {bef }}$ & $83.19 \pm 3.06^{\text {be }}$ \\
Treatment IV & $3492.54 \pm 27.9^{\text {bcef }}$ & $250.56 \pm 2.94^{\text {abcef }}$ & $81.28 \pm 1.87^{\text {abef }}$ & $86.30 \pm 3.35^{\text {be }}$ \\
Treatment V & $3117.85 \pm 39.2^{\text {abcd }}$ & $201.97 \pm 3.65^{\text {abcdf }}$ & $51.84 \pm 2.30^{\text {abcdf }}$ & $96.65 \pm 4.52^{\text {acdf }}$ \\
Treatment VI & $3193.17 \pm 64.16^{\text {abcd }}$ & $214.37 \pm 3.83^{\text {abcde }}$ & $64.59 \pm 3.89^{\text {abcde }}$ & $82.17 \pm 4.01^{\text {be }}$ \\
\hline
\end{tabular}

Treatment I: control; Treatment II: doxorubicin; Treatment III: $R$. canina extract $100 \mathrm{mg} / \mathrm{kg}$; Treatment IV: $R$. canina extract $200 \mathrm{mg} / \mathrm{kg}$; Treatment V: $R$. canina100 mg/kg /doxorubicin; Treatment VI: $R$. canina $200 \mathrm{mg} / \mathrm{kg} /$ doxorubicin (mean + SEM; P < 0.05). a Significant compared with I; ${ }^{\text {b }}$ Significant compared with II; " Significant compared with III, d Significant compared with IV; e Significant

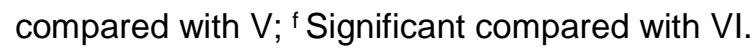

\section{Tubular frequency according to the different germ cell types}

The frequency of seminiferous tubule sections containing of Sertoli cells and different spermatogenic cell types (types A spermatogonial, preleptotene spermatocytes, pachytene spermatocytes, round spermatids and elongated spermatids) in the treatment II was significantly lower compared to those from other treatment groups at the same stage (VII) $(p<0.05)$ (Tab. 6; fig. 4) Conversely, these parameters were significantly higher in the treatment $\mathrm{V}$ and $\mathrm{VI}$ when compared to treatment II at the same stage (VII), respectively $(p<0.05)$. In addition, there was a significant increase in preleptotene spermatocytes, pachytene spermatocytes and round spermatids in treatment IV compared to the treatment I $(p<0.05)$.

Table 6. Frequencies of the different types of germinal lineage cells per 100 seminiferous tubule examined in mice testis after treatment with doxorubicin and $R$. canina extract in stage VII seminiferous.

\begin{tabular}{lllllll}
\hline & & & \multicolumn{2}{c}{ Spermatocytes } & \multicolumn{2}{c}{ Spermatids } \\
\cline { 3 - 7 } Groups & \multicolumn{1}{c}{ Sertoli } & $\begin{array}{c}\text { Spermatogonia } \\
\text { (type A) }\end{array}$ & PI & P & $\begin{array}{c}\text { Round } \\
\text { spermatids }\end{array}$ & $\begin{array}{c}\text { Elongated } \\
\text { spermatids }\end{array}$ \\
\hline Treatment I & $17.73 \pm 0.43^{\text {bef }}$ & $2.73 \pm 0.208^{\text {bef }}$ & $41.28 \pm 1.52^{\text {bdef }}$ & $45.20 \pm 1.63^{\text {bde }}$ & $120.06 \pm 4.50^{\text {bdef }}$ & $128.26 \pm 5.89^{\text {bef }}$ \\
Treatment II & $14.26 \pm 0.28^{\text {acdef }}$ & $0.40 \pm 0.13^{\text {acdef }}$ & $1.66 \pm 0.37^{\text {acdef }}$ & $5.46 \pm 1.12^{\text {acdef }}$ & $12.5 \pm 1.71^{\text {acdef }}$ & $69.9 \pm 4.34^{\text {acdef }}$ \\
Treatment III & $17.33 \pm 0.25^{\text {be }}$ & $2.66 \pm 0.18^{\text {bef }}$ & $39.93 \pm 2.35^{\text {bdef }}$ & $48.26 \pm 1.48^{\text {be }}$ & $122.26 \pm 4.66^{\text {bef }}$ & $126.46 \pm 4.64^{\text {bef }}$ \\
Treatment IV & $17.40 \pm 0.41^{\text {be }}$ & $2.80 \pm 0.22^{\text {bef }}$ & $48.40 \pm 1.12^{\text {abcef }}$ & $56.40 \pm 1.15^{\text {abdef }}$ & $132.46 \pm 4.40^{\text {abef }}$ & $127.93 \pm 5.45^{\text {bef }}$ \\
Treatment V & $15.53 \pm 0.35^{\text {abcd }}$ & $1.12 \pm 0.15^{\text {abcdf }}$ & $14.06 \pm 2.68^{\text {abcdf }}$ & $29.33 \pm 4.62^{\text {abcdf }}$ & $56.26 \pm 5.54^{\text {abcdf }}$ & $88.00 \pm 4.62^{\text {abcd }}$ \\
Treatment VI & $16.46 \pm 0.33^{\text {ab }}$ & $1.95 \pm 0.18^{\text {abcde }}$ & $21.80 \pm 1.34^{\text {abcde }}$ & $43.26 \pm 266^{\text {bde }}$ & $91.73 \pm 3.00^{\text {abcde }}$ & $101.06 \pm 6.77^{\text {abcd }}$ \\
\hline
\end{tabular}

$\mathrm{PI}$, preleptotene spermatocytes; P, pachytene spermatocytes. Treatment I: control; Treatment II: doxorubicin; Treatment III: $R$. canina extract $100 \mathrm{mg} / \mathrm{kg}$; Treatment IV: $R$. canina extract $200 \mathrm{mg} / \mathrm{kg}$; 
Treatment V: $R$. canina100 $\mathrm{mg} / \mathrm{kg} /$ doxorubicin; Treatment VI: $R$. canina $200 \mathrm{mg} / \mathrm{kg} /$ doxorubicin (mean + SEM; P < 0.05). a Significant compared with I; b Significant compared with II; c Significant compared with III, d Significant compared with IV; e Significant compared with V; ${ }^{\dagger}$ Significant compared with VI.

\section{DISCUSSION}

Considering the widespread use clinically of anticancer drugs such as doxorubicin against malignant tumors and their consequences to male fertility [15,2,3], fertility preservation strategies for patients undergoing chemotherapy treatment becomes an important issue [32]. Previous studies provide evidences that doxorubicin caused testicular toxicity through eliciting oxidative stress and apoptosis [4].

It demonstrated that oxidative stress involved in low sperm quality of male infertility [33]. On the other hand, despite the enzymatic and non-enzymatic antioxidants in the testes and seminal plasma, ample evidence has implied that there was a weak anti-oxidant defense system in testicular tissue and semen [11-13,34,35]. Based on this concept, a variety of antioxidants have been employed to protect the testes from anticancer drugs $[15,16]$.

Several studies revising a high antioxidant and anti-inflammatory properties of $R$. canina extract [18] showed that these properties are responsible for the protective effects against oxidative stress induced by renal reperfusion injury [36]. Moreover, it demonstrated that $R$. canina extract displayed an anti-inflammatory effect in an in vivo animal model of ulcerogenic gastric damage induced by ethanol as necrotizing [23]. The protective effect of $R$. canina extract over some other tissues has already been proven $[36,23]$, whereas, there is no report on its the protective effect regarding reproductive system.

Doxorubicin is administered to mice at doses up to $9 \mathrm{mg} / \mathrm{kg}$ [37]. The previous reports clearly indicated that the administration of doxorubicin intraperitoneally at the dose of $3 \mathrm{mg} / \mathrm{kg}$ for totally three shots (accumulated dose of $9 \mathrm{mg} / \mathrm{kg}$ ) caused retardation of testicular growth and reduction in spermatogenic function through eliciting oxidative stress and cell apoptosis [4]. On the same way, the two different doses of the $R$. canina extract were selected due to its high antioxidant and anti-inflammatory activity. It mentioned the clinical effect of $R$. canina extract $200 \mathrm{mg} / \mathrm{kg}$ was more effective [23].

Considering the long-term side effects of doxorubicin administration [37,4] and the potential of $R$. canina extract to improve treatment efficacy, the aim of this study was to verify if 100 and $200 \mathrm{mg} / \mathrm{kg}$ of $R$. canina extract [23] could reduce male infertility caused by doxorubicin in mice.

In the current study, a significantly lower body and testicular weights was observed in doxorubicin-treated mice, in comparison to the other groups as described in other experimental studies that administered doxorubicin alone [4]. Because testicular weight depends on the mass of the differentiated germ cells [38], a sharp decline of testicular weight can be explained by a high percentage of affected seminiferous tubules in doxorubicin -treated mice which are lined by only a layer of Sertoli cells and rare germ cells or tubules contained cells with degenerated degenerative characteristics [9]. Morphometrical parameters and germ cell frequencies provide more information about the 
germ cell degeneration result from the testicular damage $[38,10]$. In agreement with these reports, our results revealed that the marked reduction in morphometrical parameters and consequent decrease of testicular weight in doxorubicin treated-mice have occurred due to a massive germ cell loss $[4,39,38,10,9]$.

Earlier studies have been shown that a low dose administration of doxorubicin is able to target germ cells, mainly type A spermatogonia and can also decrease spermatogonia (intermediate spermatogonia and type B spermatogonia), primary spermatocytes and round spermatid, Sertoli cell and resulting in consequent depletion of seminiferous epithelium [7-10,40], as described in present study that administered doxorubicin alone. Doxorubicin also decreased the number of Sertoli cells [40] and caused suppression of spermatogenesis by acting through Sertoli cells [41].

In contrast, the present results showed that administration of both doses of $R$. canina extract not only no adverse effects on morphometrical parameters and the different spermatogenic cell types in the testes, but also the higher dose of $R$. canina extract (200 $\mathrm{mg} / \mathrm{kg}$ ) was more effective against this anticancer drug compared to the lower dose of the $R$. canina extract.

Considering that, in mice, a complete wave of spermatogenesis takes around 35 days, we can suppose that, pachytene spermatocytes at 14 days; late round spermatids of step 7-8 at 28 days generated from the target spermatogonia. Therefore, according to the elapsed time between treatment and the killing time of the animals applied in the present study (28 days), pachytene spermatocytes and round spermatids [31,42] were affected by doxorubicin or $R$. canina treatment. The frequency of tubular sections containing different spermatogenic cell types showed that $R$. canina treatment increased the number of preleptotene spermatocytes, pachytene spermatocytes and round spermatids. Conversely, antispermatogenic plants suppressed spermatogenesis and decreased seminiferous epithelium height by marked reductions in the number of pachytene spermatocytes and round spermatids which reflected in the number of spermatozoa in the epidydimal fluid [43]. Therefore, it can be concluded that $R$. canina extract with progression of meiotic process would increase spermatogenic cells, which were reflected in the epidydimal fluid parameters. In addition, it was noted improvement of the histopathological properties, and a distinctive reduction of the histomorphometrical damage and germ cell loss in the mice treated with $R$. canina extract/doxorubicin, in comparison to those solely doxorubicin-treated. These results are suggestive of the protective effect of the $R$. canina extract against doxorubicin gonadotoxicity.

The impact of the nutritional environment as an important aspect has been demonstrated on male reproduction in mammals [44]. Non-enzymatic antioxidant system is mainly including proanthocyanidins, flavonoids, vitamin E, A, C [45-49]. As previously referred, $R$. canina are known to have some these active constituents and particularly vitamin $C$ [21,50]. The importance of vitamin $C$ in the support of spermatogenesis may explain at least in part through its ability to reduce vitamin $E$ and maintain this antioxidant in an active state [47]. Vitamin $E$ is a powerful antioxidant and a vital factor for the maintenance spermatogenesis in mammalian. Animals with deficiencies of vitamin $C$ and $E$ exhibit disruption of both spermatogenesis process and testosterone production [48]. In contrast, 
administration of vitamin C improved sperm concentration, sperm motility, testosterone production and fertility in normal animals and animal's exposure to stress $[51,52,48]$. Consistent with these reports, $R$. canina extract not only increased testosterone level in normal mice, but also it improved the reduction of testosterone level resulted from doxorubicin treatment. Despite reduction in count, viability, motility and morphology in doxorubicin treated mice $[4,9,10,16], R$. canina pretreatment improved these parameters that were compromised by doxorubicin treatment in accordance with histomorphometrical findings. The significantly higher sperm count, viability, motility and morphology obtained in $R$. canina extract alone than control corroborate these findings and leads us to believe that $R$. canina extract has protective effect against doxorubicin-induced testes gonadotoxicity.

On the other hand, it demonstrated that other free radical scavengers and antioxidants such as proanthocyanidins may cause the restoration of antioxidant defense system. Proanthocyanidins as a promising chemopreventive agent, have a protective effect in the reduce of doxorubicin-induced mutagenesis and cell proliferation changes in somatic and germ cells and as well as improved sperm parameters of mice since it serves as free radical scavengers and antioxidants [15,45]. Similar results have also been described in Crataegus monogyna fruit aqueous extract, since this extract is rich in proanthocyanidins and flavonoids [53,54] and many of phenolic compounds with cytoprotective properties by scavenging radicals [55]. Crataegus monogyna co-treatment would effectively offset the oxidative impact imposed by doxorubicin on the testicular and sperm parameters through restoration of antioxidant defense system [16]. Therefore, the present study corroborates the critical role of this agent in improving the quality of the semen profile through restoration of antioxidant defense system.

\section{CONCLUSION}

In conclusion, our results indicate that $R$. canina extract is able to improve testicular and sperm parameters in mice treated with doxorubicin. The present study is the first study to investigate the protective effect of $R$. canina extract against doxorubicin-induced testicular toxicity. Further studies maybe needed to further investigate the potential role of $R$. canina extract as antioxidant agent on the male reproductive system.

Funding: This research did not receive any specific grant from funding agencies in the public, commercial, or not-for-profit sectors.

Acknowledgements: This study was supported by Faculty of Sciences from the Razi University. Author would like to thank Dr. Seyed Mohammad Masoumi for plant identification.

Conflicts of Interest: The authors declare that they have no competing interests.

\section{REFERENCES}

1. Konopa, J. G2 block induced by DNA crosslinking agents and its possible consequences. Biochem Pharmacol 1988, 37(12), 2303-2309.

2. Thorn, C.F.; Oshiro, C.; Marsh, S.; Hernandez-Boussard, T.; McLeod, H.; Klein, T.E.; et al. Doxorubicin pathways: pharmacodynamics and adverse effects. Pharmacogenet Genomics 2011, 21(7), 440-446. 
3. Sridevi, T.; Nisha, P.V.; Appavu Arulnathan, G. Effect of Doxorubicin on the morphology, histology and karyology of male reproductive system of white mice, Mus musculus. Indian $\mathrm{J}$ Sci Technol 2012, 5, 2614-2618.

4. Yeh, Y.C.; Lai, H.C.; Ting, C.T.; Lee, W.L.; Wang, L.C.; Wang, K.Y.; et al. Protection by doxycycline against doxorubicin-induced oxidative stress and apoptosis in mouse testes. Biochem Pharmacol 2007, 74(7), 969-980.

5. Gewirtz, D.A. A critical evaluation of the mechanisms of action proposed for the antitumor effects of the anthracycline antibiotics adriamycin and daunorubicin. Biochem Pharmacol 1999, 57(7), 727-741.

6. Shinoda, K.; Mitsumori, K.; Yasuhara, K.; Uneyama, C.; Onodera, H.; Hirose, M.; et al. Doxorubicin induces male germ cell apoptosis in rats. Arch Toxicol 1999, 73(4-5), 274-281.

7. Lu, C.C.; Meistrich, M.L. Cytotoxic effects of chemotherapeutic drugs on mouse testis cells. Cancer Res 1979, 39(9), 3575-3582.

8. Meistrich, M.L. Effects of chemotherapy and radiotherapy on spermatogenesis. Eur Urol 1993, 23(1),136-142.

9. Cabral, R.E.L.; Okada, F.K.; Stumpp, T.; Vendramini, V.; Miraglia, S.M. Carnitine partially protects the rat testis against the late damage produced by doxorubicin administered during pre-puberty. Andrology 2014, 2(6), 931-942.

10. Vendramini, V.; Sasso-Cerri, E.; Miraglia, S.M. Amifostine reduces the seminiferous epithelium damage in doxorubicin-treated prepubertal rats without improving the fertility status. Reprod Biol Endocrinol 2010, 8, 3.

11. Gu, W.; Hecht, N.B. The enzymatic activity of $\mathrm{Cu} / \mathrm{Zn}$ superoxide dismutase does not fluctuate in mouse spermatogenic cells despite mRNA changes. Exp Cell Res 1997, 232(2), 371-375.

12. Aitken, R.J.; Buckingam, D.W.; Carreras, A.; Irvine, D.S. Superoxide dismutase in human sperm suspensions: relationship with cellular composition, oxidative stress, and sperm function. Free Rad Biol Med 1996, 21(4), 495- 504.

13. Zini, A.; de Lamirande, E.; Gagnon, C. Reactive oxygen species in semen of infertile patients: levels of superoxide dismutase and catalase - like activities in seminal plasma and spermatozoa. Int J Androl 1993, 16(3),183-188.

14. Talevi, R.; Barbato, V.; Fiorentino, I.; Braun, S.; Longobardi, S.; Gualtieri, R. Protective effects of in vitro treatment with zinc, d-aspartate and coenzyme q10 on human sperm motility, lipid peroxidation and DNA fragmentation. Reprod Biol Endocrinol 2013, 11, 81.

15. Attia, S.M.; Al-Bakheet, S.A.; Al-Rasheed, N.M. Proanthocyanidins produce significant attenuation of doxorubicin-induced mutagenicity via suppression of oxidative stress. Oxid Med Cell Longev 2010, 3(6), 404-413.

16. Shalizar Jalali, A.; Hasanzadeh, S. Crataegus monogyna fruit aqueous extract as a protective agent against doxorubicin-induced reproductive toxicity in male rats. Avicenna $J$ Phytomed 2013, 3(2), 159-170.

17. Halvorsen, B.L.; Holte, K.; Myhrstad, M.C.; Barikmo, I.; Hvattum, E.; Remberg, S.F.; et al. A systematic screening of total antioxidants in dietary plants. J Nutr 2002, 132, 461-471.

18. Mármol, I.; Sánchez-de-Diego, C.; Jiménez-Moreno, N.; Ancín-Azpilicueta, C.; Jesús Rodríguez-Yoldi, M. Therapeutic Applications of Rose Hips from Different Rosa Species. Int J Mol Sci 2017, 18(6), 1137.

19. Serteser, A.; Kargioglu, M.; Gök, V.; Bagci, Y.; Özcan, M.M.; Arslan, D. Determination of antioxidant effects of some plant species wild growing in Turkey. Int J Food Sci Nutr 2008, 59(7-8), 643-651.

20. Ercisli, S. Chemical composition of fruits in some Rose (Rosa spp.) species. Food Chem 2007, 104, 1379-1384.

21. Chrubasik, C.; Roufogalis, B.D.; Müller-Ladner, U.; Chrubasik, S. A systematic review on the Rosa canina effect and efficacy profiles. Phytother Res 2008, 22(6), 725-733.

22. Kizilet, H.; Kasimoglu, C.; Uysal, H. Can the Rosa canina plant be used against alkylating agents as a radical scavenger?. Pol J Environ Stud 2013, 22(4), 1263-1267.

23. Lattanzioa, F.; Grecob, E.; Carrettaa, D.; Cervellati, R.; Govonic, P.; Speronia, E. In vivo anti-inflammatory effect of Rosa canina L. extract. J Ethnopharmacol 2011, 137(1), 880-885.

24. Selvakumar, E.; Prahalathan, C.; Mythili, Y.; Varalakshmi, P. Beneficial effects of DL-alpha-lipoic acid on cyclophosphamide induced oxidative stress in mitochondrial fractions of rat testis. Chem Biol Intract 2005, 152(1), 59-66.

25. Atessahin, A.; Turk, G.; Karahan, I.; Yilmaz, S.; Ceribasi, A.O.; Bulmus, O. Lycopene prevents adriamycin-induced testicular toxicity in rats. Fertil Steril 2006, 85(1), 1216-1222. 
26. Zare, Z.; Mohammadi, M.; Eimani, H.; Shafaroudi, M.M. Prevention of di (2-ethylhexyl) Phthalate-induced Testicular Disturbance in Mice by Co-administration of L-carnitine. Int $\mathrm{J}$ Fertil Steril. 2011, 5(3), 186-192.

27. Seed, J.; Chapin, R.E.; Clegg, E.D.; Dostal, L.A.; Foote, R.H.; Hurtt, M.E.; Klinefelter, G.R.; Makris, S.L.; Perreault, S.D.; Schrader, S.; Seyler, D.; Sprando, R.; Treinen, K.A.; Veeramachaneni, D.N.; Wise, L.D.; et al. Methods for assessing sperm motility, morphology, and counts in the rat, rabbit, and dog: a consensus report. Reprod Toxicol 1996, 10(3), 237-244.

28. Solati, J.; Hajikhani, R.; Toodeh Zaeim, R. Effects of cypermethrin on sexual behaviour and plasma concentrations of pituitary-gonadal hormones. Int J Fertil Steril 2010, 4, 8-23.

29. de Oliva, S.U.; Miraglia, S.M. Carbamazepine damage to rat spermatogenesis in different sexual developmental phases. Int J Androl 2009; 32(5), 563-574.

30. Taki, T.M.; Nickerson, P.A. Validation of cell volume determination for stereological studies of adrenocortical cells: comparison of values from semifine sections with those of dissociated zona faciculata cells. Am J Anat 1984, 171(4), 415-426.

31. Nakata, H.; Wakayama, T.; Takai, Y.; Iseki, S. Quantitative Analysis of the Cellular Composition in Seminiferous Tubules in Normal and Genetically Modified Infertile Mice. J Histochem Cytochem 2015; 63(2):99-113.

32. Tschudin, S.; Bitzer, J. Psychological aspects of fertility preservation in men and women affected by cancer and other life-threatening diseases. Hum Reprod Update 2009, 15(5), 587-597.

33. Hosseinzadeh Colagar, A.; Pouramir, M.; Tahmasbpour Marzony, E.; Jorsaraei, S.G.A. Relationship between Seminal Malondialdehyde Levels and Sperm Quality in Fertile and Infertile Men. Braz Arch Biol Technol 2009, 52 (6), 1387-1392.

34. Vernet, P.; Aitken, R.J.; Drevet, J.R. Antioxidant strategies in the epididymis. Mol Cell Endocrinol 2004, 216(1-2), 31-39.

35. Rao, B.; Soufir, J.C.; Martin, M.; David, G. Lipid peroxidation in human spermatozoa as related to midpiece abnormalities and motility. Gamete Res 1989, 24(2), 127-134.

36. Changizi Ashtiyani, S.; Najafi, H.; Jalalvandi, S.; Hosseinei, F. Protective Effects of Rosa Canina L Fruit Extracts on Renal Disturbances Induced by eperfusion Injury in Rats. Iranian $J$ Kidney Dis 2013, 7(4), 290-298.

37. Kang, J.; Lee, Y.; No, K.; Jung, E.; Sung, J.; Kim, Y.; et al. Ginseng intestinal metabolite-I (GIM-I) reduces doxorubicin toxicity in the mouse testis. Reprod Toxicol 2002, 16(3), 291-298.

38. Katoh, C.; Kitajima, S.; Saga, Y.; Kanno, J.; Horii, I.; Inoue, T. Assessment of quantitative dual-parameter flow cytometric analysis for the evaluation of testicular toxicity using cyclophosphamide- and ethinylestradioltreated rats. J Toxicol Sci 2002, 27(2), 87-96.

39. França, L.R.; Russel, L.D. The testis of domestic animals. Male reproduction: a multidisciplinary overview Madrid: Churchill Communications. 1998, 198-219.

40. Takahashi, H.; Tainaka, H.; Umezawa, M.; Takeda, K.; Tanaka, H.; Nishimune, Y.; et al. Evaluation of testicular toxicology of doxorubicin based on microarray analysis of testicular specific gene expression. $J$ toxicol sci 2011, 36(5), 559-567.

41. Sharpe, R.M.; Mckinnell, C.; Kivlin, C.; Fisher, J.S. Proliferation and functional maturation of Sertoli, and their relevance to disorders of testis function in adulthood. Reproduction 2003, 125(6), 769-784.

42. Clegg, E.J. The age at which male rats become fertile. J Reprod Fert 1960, 1, 118-119.

43. Singh, A.; Singh, S.K. Reversible antifertility effect of aqueous leaf extract of Allamanda cathartica L. in male laboratory mice. Andrologia 2008, 40(6), 337-345.

44. Wong, W.Y.; Thomas, C.M.; Merkus, J.M.; Zielhuis, G.A.; Steegers-Theunissen, R.P. Male factor subfertility: possible causes and the impact of nutritional factors. Fertil Steril 2000, 73(3), 435- 442.

45. Bagchi, D.; Garg, A.; Krohn, R.L.; Bagchi, M.; Tran, M.X.; Stohs, S.J. Oxygen free radical scavenging abilities of vitamins $\mathrm{C}$ and $\mathrm{E}$, and a grape seed proanthocyanidin extract in vitro. Res Commun Mol Pathol Pharmacol 1997, 95(2), 179-189.

46. Bravo, L. Polyphenols: chemistry, dietary sources, metabolism, and nutritional significance. Nutr Rev 1998, 56(11), 317-333.

47. Paolicchi, A.; Pezzini, A.; Saviozzi, M.; Piaggi, S.; Andreuccetti, M.; Chieli, E.; et al. Localization of a GSH-dependent dehydroascorbate reductase in rat tissues and subcellular fractions. Arch Biochem Biophys 1996, 333(2), 489-495.

48. Johnson, F.C. The antioxidant vitamins CRC. Crit Rev Food Sci Nutr 1979, 11(3), 217--309.

49. Yoganathan, T.; Eskild, W.; Hansson, V. Investigation of detoxification capacity of rat testicular germ cells and Sertoli cells. Free Radic Biol Med 1989, 7(4), 355-359. 
50. Czyzowska, A.; Klewicka, E.; Pogorzelski, E.; Nowak, A. Polyphenols, vitamin C and antioxidant activity in wines from Rosa canina L. and Rosa rugosa thunb. J Food Comp Anal 2015, 39, 62-68.

51. Sonmez, M.; Turk, G.; Yuce, A. The effect of ascorbic acid supplementation on sperm quality, lipid peroxidation and testosterone levels of male Wistar rats. Theriogenology 2005, 63(7), 2063-2072.

52. Rekha, D.K.; Nayanatara, A.K.; Ramaswamy C.; Sheila, R.P.; Ramesh Bhat, M.; Venkappa, S.M. Infertility in male wistar rats induced by cadmium chloride: role of ascorbid acid. $J$ Chinese Clin med 2009; 4(11), 616-621.

53. Bahorun, T.; Gressier, B.; Trotin, F.; Brunet, C.; Dine, T.; Luyckx, M.; et al. Oxygen species scavenging activity of phenolic extracts from hawthorn fresh plant organs and pharmaceutical preparations. Arzneimittelforschung 1996, 46(11), 1086-1089.

54. Ljubuncic, P.; Azaizeh, H.; Portnaya, I.; Cogan, U.; Said, O.; Saleh, K.A.; et al. Antioxidant activity and cytotoxicity of eight plants used in traditional Arab medicine. J Ethnopharmacol 2005, 99(1), 43-47.

55. Bahorun, T.; Trotin, F.; Pommery, J.; Vasseur, J.; Pinkas, M. Antioxidant activities of Crataegus monogyna extracts. Planta Medica 1994, 60(4), 323-328. 